\title{
Optimization of Spacing and Fertilizer Levels on Growth of Sesame (Sesamum indicum L.)
}

\author{
G.B. Unde, V.P. Suryavanshi and R.S. Shinde* \\ Department of Agronomy, College of Agriculture, Vasantrao Naik Marathwada Agriculture \\ University, Latur - 413512, Maharashtra, India \\ *Corresponding author
}

\section{A B S T R A C T}

\section{Keywords}

Plant spacing, Fertilizer, Sesame (Sesamum indicum L.).

Article Info

Accepted:

19 October 2017

Available Online:

10 December 2017
A field experiment was conducted during kharif season of 2014-15 at Oilseeds Research Station, Latur, to study the response of sesame to different spicing and fertilizer levels. The experiment was laid out in a split plot design consisting six spacing and three fertilizer levels with two replications. The results indicated that growth and yield attributing characters of sesame viz. plant height, number of functional leaves, leaf area, number of capsule, number of branches, total dry matter, capsule yield per plant and test weight were appreciably improved with the spacing of $60 \mathrm{~cm} \times 15\left(\mathrm{~S}_{6}\right) \mathrm{cm}$ the spacing of $45 \mathrm{~cm} \times 10$ $\mathrm{cm}\left(\mathrm{S}_{1}\right)$ was found to be significantly effective in producing higher seed yield $\left(\mathrm{kg} \mathrm{ha}^{-1}\right)$, oil yield $\left(\mathrm{kg} \mathrm{ha}^{-1}\right)$, gross monetary returns, net monetary returns and $\mathrm{B}$ : $\mathrm{C}$ ratio which was at a par with the spacing of $30 \mathrm{~cm} \times 15 \mathrm{~cm}\left(\mathrm{~S}_{2}\right)$ and significantly superior over rest of the spacing. Among different fertilizer levels, the application of $125 \% \operatorname{RDF}\left(\mathrm{F}_{3}\right)$ produced significantly higher growth and yield attributing characters, higher seed yield $\left(\mathrm{kg} \mathrm{ha}^{-1}\right)$, oil yield $\left(\mathrm{kg} \mathrm{ha}^{-1}\right)$, gross monetary returns, net monetary returns and $\mathrm{B}: \mathrm{C}$ ratio as compared to $75 \% \operatorname{RDF}\left(\mathrm{F}_{1}\right)$ and it was at par with $100 \% \operatorname{RDF}\left(\mathrm{F}_{2}\right)$.

\section{Introduction}

Sesame (Sesamum indicum L.) which is known variously as til, gingelly, simsim, gergelim etc. Sesame is one of the world's oldest cultivated oilseed crops. Sesame is a self-pollinated crop, which belongs to family Pedaliaceae and better known as "Queen of oilseeds" by virtue of its quality edible oil and protein content, as it contains 50 percent oil and 18-20 percent protein. Sesame oil has long shelf life and rich in linoleic acid. Its protein is rich in sulphur containing amino acid (Methionine). Yield potential of sesame can be exploited by the use of agronomic techniques. Among the standardized agronomic practices required for a realizing yield potential of kharif sesame, plant geometry and nutrition are the most important factors in determining yield. The planting geometry helps in altering canopy architecture affecting light interception and $\mathrm{CO}_{2}$ assimilation which further affect the productivity. Plant nutrition is key input to increase the productivity. Fertilizer is an important option that should be adopted in order to improve crop yields. Nitrogen is a structural component of chlorophyll and protein therefore adequate supply of nitrogen is beneficial for both carbohydrates and protein metabolism. Similarly, phosphorus is an important plant nutrient which help in 
growth and development of a plant and ultimately improved crop yield. Supply of nutrients and water to the growing plant parts, resulting in increased growth and yield traits, thereby ensuring more seed and dry matter yield (Maiti and Jana, 1985). It significantly increases seeds capsule ${ }^{-1}$, capsule plant ${ }^{-1}$, seed yield, oil and protein content of sesame cultivar. Understanding the dynamic of these nutrients in terms of their uptake, translocation and distribution in sesame plant with an important aspect of its nutrition that will help in taking decision to improve its production and management. It will also help in adaptation of proper package and practices for sesame crop and reduce the cost of fertilization. In view of above consideration the present investigation entitled "Optimization of spacing and fertilizer level in sesame (Sesamum indicum L.)"

\section{Materials and Methods}

A field experiment was conducted during kharif season of 2014-15 at Oilseeds Research Station, Latur, to study the response of sesame to different spacing's and fertilizer levels. The soil was clayey in texture, low in available nitrogen (141 kg ha $\left.{ }^{-1}\right)$, medium in phosphorus $\left(17.1 \mathrm{~kg} \mathrm{ha}^{-1}\right)$, high in potassium $\left(576 \mathrm{~kg} \mathrm{ha}^{-1}\right)$ and slightly alkaline in reaction $\left(7.8 \mathrm{P}^{\mathrm{H}}\right)$. The total rainfall received during crop growth period was $421 \mathrm{~mm}$ and distributed over 29 rainy days. The experiment was laid out in a split plot design consisting six spacing's viz. $45 \mathrm{~cm} \mathrm{x} 10 \mathrm{~cm}$ $\left(\mathrm{S}_{1}\right), 30 \mathrm{~cm} \times 15 \mathrm{~cm}\left(\mathrm{~S}_{2}\right), 45 \mathrm{~cm} \times 15 \mathrm{~cm}\left(\mathrm{~S}_{3}\right)$, $30 \mathrm{~cm} \times 22.5 \mathrm{~cm}\left(\mathrm{~S}_{4}\right), 60 \mathrm{~cm} \times 10 \mathrm{~cm}\left(\mathrm{~S}_{5}\right)$ and $60 \mathrm{~cm} \times 15 \mathrm{~cm}\left(\mathrm{~S}_{6}\right)$ as main plot treatment and three fertilizer levels viz. $75 \% \operatorname{RDF}\left(\mathrm{F}_{1}\right)$, $100 \% \operatorname{RDF}\left(\mathrm{F}_{2}\right)$ and $125 \% \operatorname{RDF}\left(\mathrm{F}_{3}\right)$ as sub plot treatment replicated twice. The recommended dose of fertilizer (RDF) was 50: 25: 00 NPK kg ha ${ }^{-1}$. The gross and net plot size of expérimental unit was 5.4 x $3.6 \mathrm{~m}$ and 4.5/4.8/4.2 x $3.0 \mathrm{~m}$ respectively. Sowing was done by dibbling method on $12^{\text {th }}$ July 2014. The recommended cultural practices and plant protection measures were under taken as per recommandation. Data on various variables were analyse by analysis of variance (Panse and Sukhatme, 1967)

\section{Results and Discussion}

The data pertaining to growth parameters have been presented in table 1 . The important growth parameters plant height $(\mathrm{cm})$, number of branches per plant, leaf area $\left(\mathrm{dm}^{2}\right)$, number of functional leaves plant ${ }^{-1}$, and total dry matter $(\mathrm{g})$. were influanced significantlly by various treatment.

Among the various spacing's the spacing of $60 \mathrm{~cm} \times 15 \mathrm{~cm}\left(\mathrm{~S}_{6}\right)$ produced significantly highest plant height at all growth stages of crop growth except 15 DAS and spacing of 30 $\mathrm{cm} \times 15 \mathrm{~cm}\left(\mathrm{~S}_{2}\right)$ produced lowest plant height through crop growth period except at 15 DAS. The wider row and plant spacing might have provided sufficient rooting and moisture extraction pattern to the plant which in turn would have helped better absorption of water and nutrient from the soil resulting in tallest plant. This is in agreement with the findings Sivagamy and Rammohan (2013), Shinde et al., (2011) and Caliskan et al., (2004).

The plant spacing of $60 \mathrm{~cm} \times 15 \mathrm{~cm}\left(\mathrm{~S}_{6}\right)$ recorded significantly higher mean number of functional leaves per plant as compared to all other spacings. The spacing of $45 \mathrm{~cm} \times 10 \mathrm{~cm}$ $\left(\mathrm{S}_{1}\right)$ and $30 \mathrm{~cm} \mathrm{x} 15 \mathrm{~cm}\left(\mathrm{~S}_{2}\right)$.

Availability of sufficient light and moisture to every plant at higher plant spacing leading to enhanced plant growth might have led to better functional leaves per plant Basavraj et al., (1993). Mean leaf area per plant was increased up to 60 DAS. The significant differences in leaf area were observed among different spacing at all growth stages. 
Table.1 Data pertaining to growth parameters

\begin{tabular}{|c|c|c|c|c|c|c|}
\hline Treatment & $\begin{array}{c}\text { Plant } \\
\text { height } \\
(\mathbf{c m})\end{array}$ & $\begin{array}{c}\text { Number } \\
\text { of } \\
\text { functional } \\
\text { leaves }\end{array}$ & $\begin{array}{l}\text { Mean leaf } \\
\operatorname{area}\left(\mathbf{d m}^{2}\right)\end{array}$ & $\begin{array}{c}\text { Number } \\
\text { of } \\
\text { branches } \\
\text { plant- }^{1}\end{array}$ & $\begin{array}{c}\text { Total } \\
\text { dry } \\
\text { matter } \\
(g)\end{array}$ & $\begin{array}{c}\text { Yield } \\
\left(\text { kg ha- }^{1}\right)\end{array}$ \\
\hline \multicolumn{7}{|l|}{ Spacings (cm) } \\
\hline$S_{1}-45 \times 10$ & 88.4 & 17.10 & 15.66 & 4.12 & 22.08 & 658 \\
\hline$S_{2}-30 \times 15$ & 83.6 & 11.18 & 16.17 & 3.90 & 24.19 & 597 \\
\hline$S_{3}-45 \times 15$ & 85.4 & 10.03 & 22.13 & 3.97 & 21.87 & 543 \\
\hline $\mathrm{S}_{4}-30 \times 22.5$ & 88.7 & 13.82 & 21.26 & 4.03 & 25.30 & 486 \\
\hline$S_{5}-60 \times 10$ & 94.9 & 7.96 & 22.25 & 4.03 & 22.38 & 576 \\
\hline$S_{6}-60 \times 15$ & 98.7 & 20.28 & 27.44 & 4.17 & 35.93 & 545 \\
\hline S.E. \pm & 2.3 & 0.41 & 1.16 & 0.03 & 0.84 & 17 \\
\hline C.D. at $5 \%$ & 8.4 & 1.50 & 4.22 & 0.11 & 3.05 & 63 \\
\hline \multicolumn{7}{|l|}{ Fertilizer levels } \\
\hline $\mathrm{F}_{1}-75 \% \mathrm{RDF}$ & 86.9 & 10.38 & 17.83 & 3.89 & 22.47 & 535 \\
\hline $\mathrm{F}_{2}-100 \% \mathrm{RDF}$ & 89.7 & 14.27 & 21.27 & 4.07 & 25.64 & 576 \\
\hline $\mathrm{F}_{3}-125 \% \mathrm{RDF}$ & 93.2 & 15.53 & 23.36 & 4.15 & 27.76 & 592 \\
\hline S.E. \pm & 1.4 & 0.40 & 0.70 & 0.04 & 0.76 & 13 \\
\hline C.D. at $5 \%$ & 4.2 & 1.24 & 2.17 & 0.12 & 2.35 & 41 \\
\hline \multicolumn{7}{|c|}{ Interaction $(\mathrm{S} \times \mathrm{F})$} \\
\hline S.E. \pm & 3.36 & 0.98 & 1.72 & 0.10 & 1.8 & 32 \\
\hline C.D. at $5 \%$ & NS & NS & NS & $\mathrm{NS}$ & $\mathrm{NS}$ & $\mathrm{NS}$ \\
\hline General Mean & 89.96 & 13.39 & 20.81 & 4.03 & 25.29 & 568 \\
\hline
\end{tabular}

Among the spacing the spacing of $60 \mathrm{~cm} \mathrm{x} 15$ $\mathrm{cm}\left(\mathrm{S}_{6}\right)$ was significantly higher leaf area per plant which was at par with $60 \mathrm{~cm} \times 10 \mathrm{~cm}\left(\mathrm{~S}_{5}\right)$, $30 \mathrm{~cm} \times 22.5 \mathrm{~cm}\left(\mathrm{~S}_{4}\right), 45 \mathrm{~cm} \times 15 \mathrm{~cm}\left(\mathrm{~S}_{3}\right)$ at different growth stages spacing of $60 \mathrm{~cm} \times 15$ $\mathrm{cm}\left(\mathrm{S}_{6}\right)$ produced significantly higher leaf area per plant over rest of the spacings. Similar result was also obtained by Sarkar and Pal (2005).

The spacing of $60 \mathrm{~cm} \times 15 \mathrm{~cm}\left(\mathrm{~S}_{6}\right)$ produced significantly higher mean number of branches per plant which was at par with $45 \mathrm{~cm} \times 10 \mathrm{~cm}$ $\left(\mathrm{S}_{1}\right)$ found significantly superior over rest of the spacings at different growth stages. The wider plant spacing $60 \mathrm{~cm} \times 15 \mathrm{~cm}\left(\mathrm{~S}_{6}\right)$ enhanced mean number of branches over remaining spacing owing to better geometric arrangement resulting in better absorption of moisture and nutrient due to lesser competition for growth factors between plant. Similar finding were also observed by Sivagamy and Rammohan (2013) and Jukusko and Usman (2013). The spacing of $60 \mathrm{~cm} \times 15 \mathrm{~cm}\left(\mathrm{~S}_{6}\right)$ recorded significantly higher mean total dry matter per plant over rest of the spacing. The extent of increases in the dry matter per plant due to decreases in plant density tended to increases growth advanced. Thus the increased total dry matter per plant at wider plant spacing which usually associated with increased leaf area per plant has led to greater accumulation of photosynthesis. Similar findings reported by Ngala et al., (2013) and Haruna (2011).

Seed yield $\left(\mathrm{kg} \mathrm{ha}^{-1}\right)$ was influenced significantly due to different spacing. The spacing of $45 \mathrm{~cm} \mathrm{x}$ $10 \mathrm{~cm}\left(\mathrm{~S}_{1}\right)$ produced significantly highest seed yield $\left(\mathrm{kg} \mathrm{ha}^{-1}\right)$ which was at par with $30 \mathrm{~cm} \times 15$ $\mathrm{cm}\left(\mathrm{S}_{2}\right)$ and significantly superior over rest of spacings. It might be due to higher plant population in closer spaced plant. Hence higher 
plant population lead to higher seed yield per unit area. Similarly yield reduction with decreasing plant population in sesame reported by Prasanna et al., (2014).

From the result it may be inferred that the plant spacing of $60 \mathrm{~cm} \times 15 \mathrm{~cm}\left(\mathrm{~S}_{6}\right)$ was recorded with higher plant height $(\mathrm{cm})$, Number of functional leaves, mean leaf area $\left(\mathrm{dm}^{2}\right)$, number of branches plant ${ }^{-1}$, total dry matter $(\mathrm{g})$ and highest yield $\mathrm{kg} \mathrm{ha}^{-1}$ was recorded with closer plant spacing $\left(\mathrm{S}_{1}\right)-45 \times 10 \mathrm{~cm}$ that was $(658 \mathrm{~kg}$ $\mathrm{ha}^{-1}$ ) over the other plant spacing.

\section{References}

Basavaraj, B., R. A. Shetty, and C. S. Hunshal (1993) Study the response of sesame varieties to fertilizer and population levels in paddy lands of Tunga Bhadra Project Area during summer. Karnataka $J$. Agril.Sci., 13 (1); 138-140.

Caliskan, S., M. Arslan, H. Arigolu and N. Isler (2004) Effect of planting method and plant population on growth and yield of sesame (Sesamum indicum L.) in a Mediterranean type of environment, Aissian J. Plant Sci., 3 (5): 610-613.

Haruna, I.M. (2011) Growth and Yield of Sesame (Sesamum indicum L.) as influenced by Nitrogen and Intra row spacing in Lafia, Nasarawa State of Nigeria. Elixir Agriculture, 41:56855688.

Jakusko, B.B. and B.D. Usman (2013) Effects of $\mathrm{npk}$ fertilizer and plant population density on productivity of sesame (Sesamum indicum L.) Res. J. Agril Envirn. Management, 2 (5): 121-126.
Maiti, D. D. and Jana, P. K. (1985) Effect of different levels of nitrogen and phosphorous on yield and yield attributes of sesame. Oilseeds Res., 2:252-259.

Ngala, A.L., I.Y. Dugje and H. Yakub (2013) Effect of inter row spacing and plant density on performance of sesame (Sesamum indicum L.) in a Nigerian Sudan Savana, Sci. Int. (Lahore), 25 (3): 513-519.

Prasanna Kumara B. H., B. M. Chittapur, S. M. Hiremath, L. H. Malligwad, H. L. Nadaf And R. V. Koti (2014) effect of fertilizer levels and planting geometry on the performance of sesame (sesamum indicum 1.) Genotypes Karnataka J. Agric. Sci., 27 (3): 289-292.

Sarkar, R.K. and P.K. Pal (2005) Effect of crop geometry, fertility level and nipping on physiological parameter in relation to productivity of sesame (Sesamum indicum L.). Indian J. Agril. Sci., 75(3): 143-147.

Shinde, S. D., B. S. Raskar and B. D. Tomboli (2011) Effect of spacing and sulphur levels on productivity of sesame (Sesamum indicum L.) under summer condition. J. Agril. Res. Technol., 36(1): 028-031.

Sivagamy, K. and J. Rammohan (2004) Effect of sowing date and crop spacing on growth, yield attributes and quality of sesame. J. Agril. Veterinary Sci., 2319 (5): 38-40.

Sivagamy, K. and J. Rammohan (2004) Effect of sowing date and crop spacing on growth, yield attributes and quality of sesame. J. Agril. Veterinary Sci., 2319 (5): 38-40.

\section{How to cite this article:}

Unde, G.B., V.P. Suryavanshi and Shinde, R.S. 2017. Optimization of Spacing and Fertilizer Levels on Growth of Sesame (Sesamum indicum L.). Int.J.Curr.Microbiol.App.Sci. 6(12): 27932796. doi: https://doi.org/10.20546/ijcmas.2017.612.323 